\title{
NORMATIVE FRAMEWORK (PRECONDITIONS) \\ IN THE TRAINING OF GEOGRAPHY AND ECONOMICS IN 9-TH GRADE - LOGIC AND CHALLENGES
}

DOI: http://dx.doi.org/10.18509/GBP.2018.70

UDC: 373.3:91(497.2)

\author{
Stella Dermendzhieva \\ Tamara Draganova \\ „St. Cyril and St. Methodius” University of Veliko Tarnovo, Bulgaria
}

\begin{abstract}
Since the school year of 2016 new educational realities have been introduced in the Republic of Bulgaria. The education reform was initiated with the introduction of the new Preschool and school education Act and its regulations that define the school frame of geographical education. The education is a national priority with a new conceptual frame representing a process of education, upbringing and socialization valid as well as in the training of geography and economics.

This article presents of the training on „Geography and economics” in the new curriculum - IX -th grade, compulsory preparation. A conceptual and content-analysis were made of the place, structure and content, new concepts, areas of competence, competencies as expected results, inter-subject and interdisciplinary-subject relations, activities for acquiring key competences, atc. In new educational realities the training on „Geography and economics" has a new model for the Bulgarian secondary school.
\end{abstract}

Keywords: curriculum, conceptual analysis, Geography and economics, normative framework, school geographic education

\section{INTRODUCTION}

„, No one else can learn, you can only help him to find the knowledge in yourself."

G. Galiley

Training as an educational paradigm is the crossroads where everyone gets the knowledge, but most of all, helping to find this knowledge in and for yourselves. Normative educational documents are the carriers of knowledge, and its mentors and performers are the teachers. The students alone choose the knowledge of their worldly crossroad, with the basic idea that they have to construct their own knowledge by interacting with the knowledges they learn in the school environment of different school subjects. Constructivism as an educational strategy is present in the legal normative framework and in the geography and economics training in the Bulgarian school, ranging from the new realities of educational reform.

Geography training in the 9th grade in its main purpose and content framework is ,aimed at acquiring key competences by mastering knowledges, skills and attitudes related to the political and socio-economic organization of the society, the regions in the world and the countries in them."[5] The normative framework of geography and economics training 
in 9 grade follows the logic and challenges of educational reform and education as a national priority, in accordance with its principles of training and the main purposes determined in the Preschool and School Education Law. The structural content model of the study content in studying the geographic picture of the world: political - socio regional geography is preserved (Figure 1). The concept is preserved in continuing to build on the knowledges, skills and competences for general and regional geography.

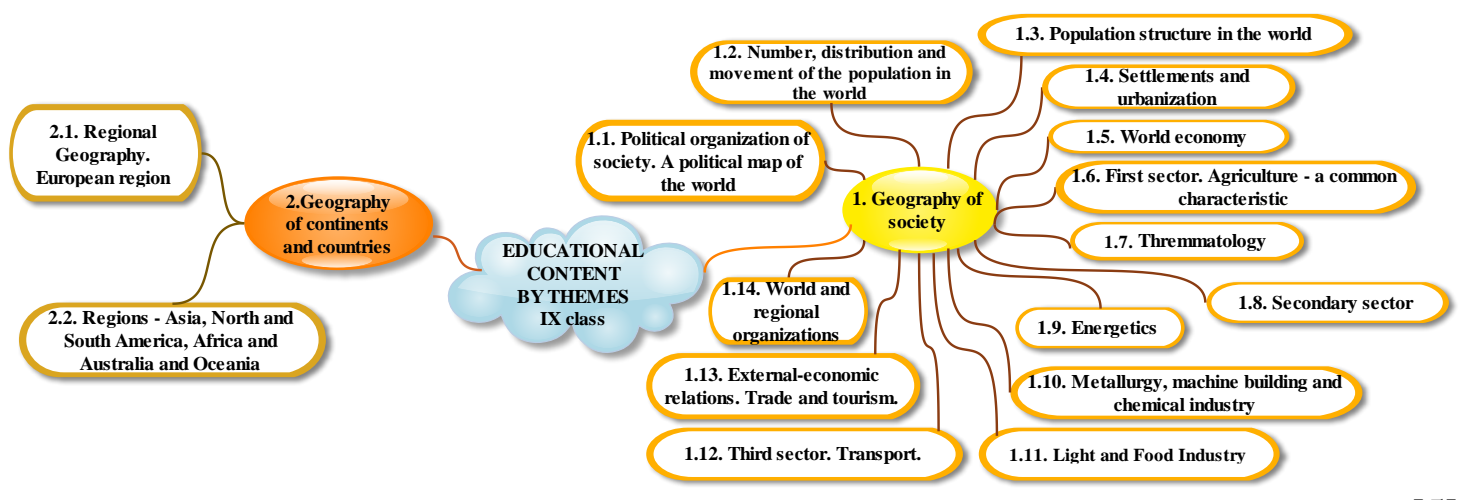

Figure 1. Mind map of the structure-content model of the study content by curriculum

It is visible the unification of political and social geography under a common name, which does not combine their substantive-content base. The logical scheme of their interrelation and interdependence is clearly defined: political organization of society - population economy - global and regional organizations. The proposed conceptual model strengthens the role and outputs the interaction of the subtopics and their meaning for the formation of an objective picture of the world. The second topic is self-titled and its title is based on the concept of the scope of continents and countries on the one side, and their regions and countries in them on the other side, without the approach of studying the regions and countries. The regions are represented and matched according to the continents studied in the vertical.

The methodological part contains the scientific approaches and methods (instrumentality) of the knowledge of the socio-economic processes and phenomena of a certain territory. Especially useful is the use of the system approach, since geography as a science and the objects of its research, in particular the territory, are by their nature are systemic. This approach involves both synthesis and analysis - disintegration of the complex systems into less complex subsystems, and disclosure of the mechanism of their interaction. Of particular importance are the analysis of the interconnections within the system and its relationship with other external systems and processes. [1]

A serious challenge for the introduction of the new curriculum in the 9th grade of the school year 2018/2019 is the time of applying of the educational reform in the Bulgarian school. Since the inception of the changes introduced by the new Education Law and the subsequent normative regulations on the training geography and economics in the 9th grade is the third year since the start of the reform. Training regulated to the learning outcomes requirements of the state educational standard and the defined competencies for knowledges, skills and attitudes are addressed by new specific training purposes and accurately referenced by area of competences.

The normative framework has preserved a long-standing educational tradition in the Bulgarian school in geography training - to study the geography of the world, a year before the geography course of the native country, which completes the compulsory 
geography preparation at the secondary school (Figure 2). The new curriculum is preserves this traditional educational concept for the school geography, as one of the principles laid down in the new Preschool and School Education Law - ,preserving and developing of the Bulgarian educational tradition" is being applied. [6] In the new educational realities, the volume was reduced and was removed from the 9th grade structure of the study of Nature's Geography, which course was taught in the 8th grade from $2017 / 2018$.

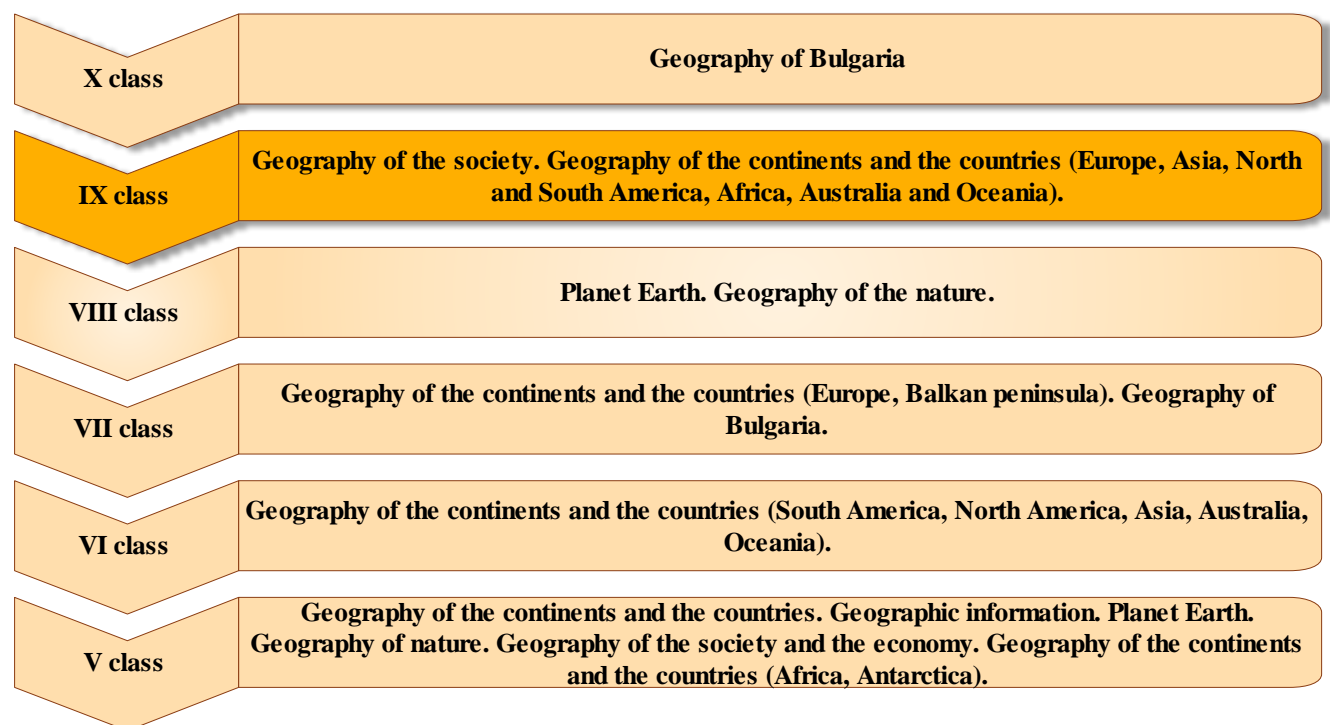

Figure 2. Place of the training in geography and economics in 9 grade in the Bulgarian school

The challenge for geography and economics training in the 9th grade is its orientation towards the interest and motivation of the students, the age and social changes in their lives, as well as the application of the acquired competencies in practice. [6] The acquisition of competencies and their application in modern civil society are the guarantor for a successful personal and professional realization of the students placed on the educational paradigm for lifelong learning.

The Ordinance on general education preparation has set the challenge at geography and economics training as part of the general education gained throughout the whole schooling - based on the main and scope of groups of key competences. As a challenge and modern aspect in the scientific and educational space, the training in 9th grade of the first high school stage of the middle degree is decomposed into nine groups of key competences - „1. competences in the field of Bulgarian language; 2. communication skills in foreign languages; 3 . mathematical competence and main competences in the field of natural sciences and technologies; 4. digital competence; 5. skills for learning; 6. social and civic competences; 7. initiative and entrepreneurship; 8 . cultural competence and skills for expression through creativity; 9. skills for support of the sustainable development and for the healthy lifestyle and sport." [4, 5] Each group from key competences provides and is needed for ,the individual's and personal development throughout life, the building of an active civic position and participation in social life, as well as its suitability for realization on the labor market." [4] The totality and interdependence of knowledges, skills and attitudes explicitly and implicitly leads to the development of critical thinking, problem solving, responsibility, creativity, teamwork, and others. 
The state educational standard (DOS) in geography and economics, which regulates the learning outcomes requirements from the training for the middle school stage of the firstgrade in which falls the 9th grade training, contains the specific purposes and expected learning outcomes (knowledges, skills and attitudes) by areas of competences and the relationship with the individual key competences. For the three areas of competences which serve the 9th grade teaching content, specific expected outcomes are presented (Table 1). At the DOS level are contained three areas of competences with a different number of expected outcomes - a total of 12 expected outcomes. [4]

Expected training outcomes and their relationship to the key competences reveal the lack of one of nine for the three areas - „communication skills in foreign languages”. The relationship is undoubtedly present implicitly and the signs of it in the activities provoked by the active verbs $1,5,10,11,12,15,16$ and 17 (Table 2). The lack of a link 4 - ,digital competence" [5] is not justified, because it determines, assists and cooperates in the realization of the expected outcomes for all three areas of a digital age and the development of information and communication technologies in all areas of education and science.

Table 1. Expected outcomes by the field of competences in 9 grade in DOS and curriculum

\begin{tabular}{|c|c|c|c|c|c|}
\hline \multicolumn{6}{|c|}{ EXPECTED RESULTS BY AREAS OF COMPETENCES } \\
\hline \multicolumn{3}{|c|}{ STATE EDUCATIONAL STANDARD } & \multicolumn{3}{|c|}{ CURRICULUM - 9 CLASS } \\
\hline $\begin{array}{c}\text { Areas of } \\
\text { competence }\end{array}$ & $\begin{array}{l}\text { Expected } \\
\text { results }\end{array}$ & Active verbs & $\begin{array}{c}\text { Areas of } \\
\text { competence }\end{array}$ & $\begin{array}{l}\text { Expected } \\
\text { results }\end{array}$ & Active verbs \\
\hline $\begin{array}{l}\text { Geography of } \\
\text { the society and } \\
\text { the economy }\end{array}$ & 5 & $\begin{array}{c}\mathbf{9} \\
\text { analyzes } \\
\text { comments (2) } \\
\text { classifies } \\
\text { explains (3) } \\
\text { knows } \\
\text { characterizes }\end{array}$ & $\begin{array}{l}\text { Geography of } \\
\text { the society }\end{array}$ & 5 & $\begin{array}{c}\mathbf{1 0} \\
\frac{\text { explains (3) }}{\text { analyze }} \\
\text { comments (3) } \\
\text { classifies } \\
\text { knows } \\
\text { characterized }\end{array}$ \\
\hline $\begin{array}{l}\text { Geography of } \\
\text { the regions and } \\
\text { the countries }\end{array}$ & 4 & $\begin{array}{c}\mathbf{8} \\
\text { describes } \\
\text { names } \\
\text { determines } \\
\text { demonstrates } \\
\text { knows } \\
\text { evalues } \\
\text { characterizes } \\
\text { comments }\end{array}$ & $\begin{array}{l}\text { Geography of } \\
\text { the regions and } \\
\text { the countries }\end{array}$ & 4 & $\begin{array}{c}\mathbf{8} \\
\text { describes } \\
\text { names } \\
\text { determines } \\
\text { demonstrates } \\
\text { knows } \\
\text { evalues } \\
\text { characterizes } \\
\text { comments }\end{array}$ \\
\hline $\begin{array}{l}\text { Geographic } \\
\text { information }\end{array}$ & 3 & $\begin{array}{c}\mathbf{5} \\
\text { identifies } \\
\text { localizing } \\
\text { interprets } \\
\text { generate } \\
\text { presents }\end{array}$ & $\begin{array}{l}\text { Geographic } \\
\text { information }\end{array}$ & 3 & $\begin{array}{c}\mathbf{5} \\
\text { identifies } \\
\text { localizing } \\
\text { interprets } \\
\text { generate } \\
\text { presents }\end{array}$ \\
\hline TOTAL & 12 & $22(17)$ & TOTAL & 12 & $23(20)$ \\
\hline
\end{tabular}

The active verbs used are a total of 17 ( 22 with three recurring verbs), characterized repeatedly 2 times, explaining - 3 times and commenting - 3 times. The active verb characterized (at the application level) is mainly focused on applying the algorithm to characterize the structure and territorial organization of the economy, as well as to characterize the specific peculiarities of the regions in the world. The active verb was used three times which explains (on a level of understanding) the ,nature and forms of 
urbanization, changes in the contemporary political map, their causes and the main forms of political organization of society, as well as the influence of the factors for the development of the world economy and the territorial its place." [4] Comment is the third active verb, which is present three times, and places an emphasis on developing and refining competences for making conclusions, justify and express personal opinion on „the problems of demographic and social development, for the consequences of urbanization and peculiarities in the natural, demographic and the economic image of countries typical representatives of regions in the world." [4] The active verbs set in the DOS are characterized by a wide variety and scope at B. Bloom's Taxonomy levels and are more determined by the productive nature of the expected outcomes (Table 2). [2]

The curriculum includes the three areas of DOS competencies by changing the name of the first area. It is not included in the name of the concept of a economy, by adopting a discourse on the scope and scientific basis of public geography and the economy as an integral part of it. Another difference is the increased application of the active verb commented. The areas of competences and the active verbs to them in the curriculum are fully in line with those of the DOS (Table 1). The active verbs used are a total of 17 (23 with three verbs with a higher frequency of use), explains was used 3 times, comments 3 times, and characterizes 2 times (Table 2). The logic in the structure and the content of the curriculum follows the DOS macroframe.

The curriculum defines a total of 42 new concepts, of which 36 are single and 6 are common. Concepts are focused on topic 1 (39 new concepts) and topic 2 (3). This balance is explained by the school content of the topics of theme 1 , which is transformed into a particular region and country (s) in theme 2. [5]

A new foreshortening in the curriculum in 9th grade is recommended percentage distribution of the school hours by the types of lessons (Figure 3). A positive side and challenge in geography training is the increased number of lessons for activities. The logic of predominance of lessons for new knowledges in the structure of lesson types is preserved.
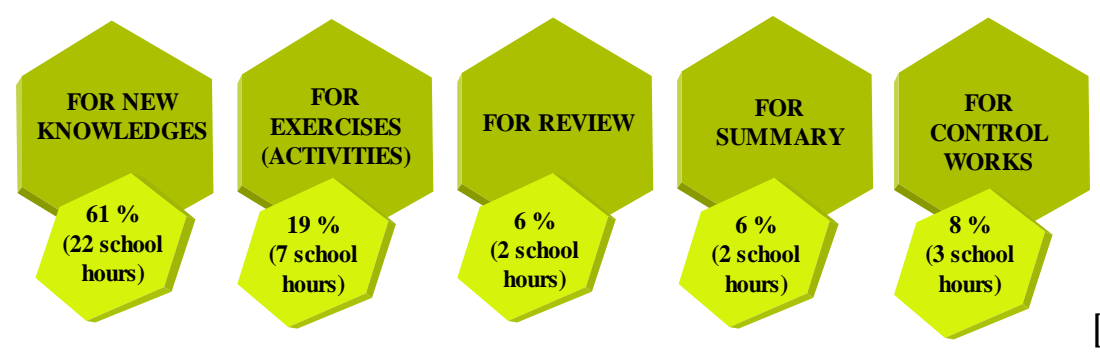

Figure 3. Distribution of lesson types in 9 class by curriculum

The model of construction of the school content in geography and economics in 9 grade is spiral. The school content is divided into two main themes, with the first subject Geography of the society (14 themes), and a lesser part (2 topics) of the Regional geography.

The challenge in the geography training in 9th grade are defined activities for the acquisition of key competencies. The curriculum contains specifically scheduled activities to the six key competencies. The highlights are placed on expressing opinion on geographic questions; bringing out the conclusions; formulation of the evidences and assessment of objects, processes and phenomena; making schemes, circuits, tables, maps; use of the information technologies; case solving and argumentation decisions; teamwork and others with an interactive character. 


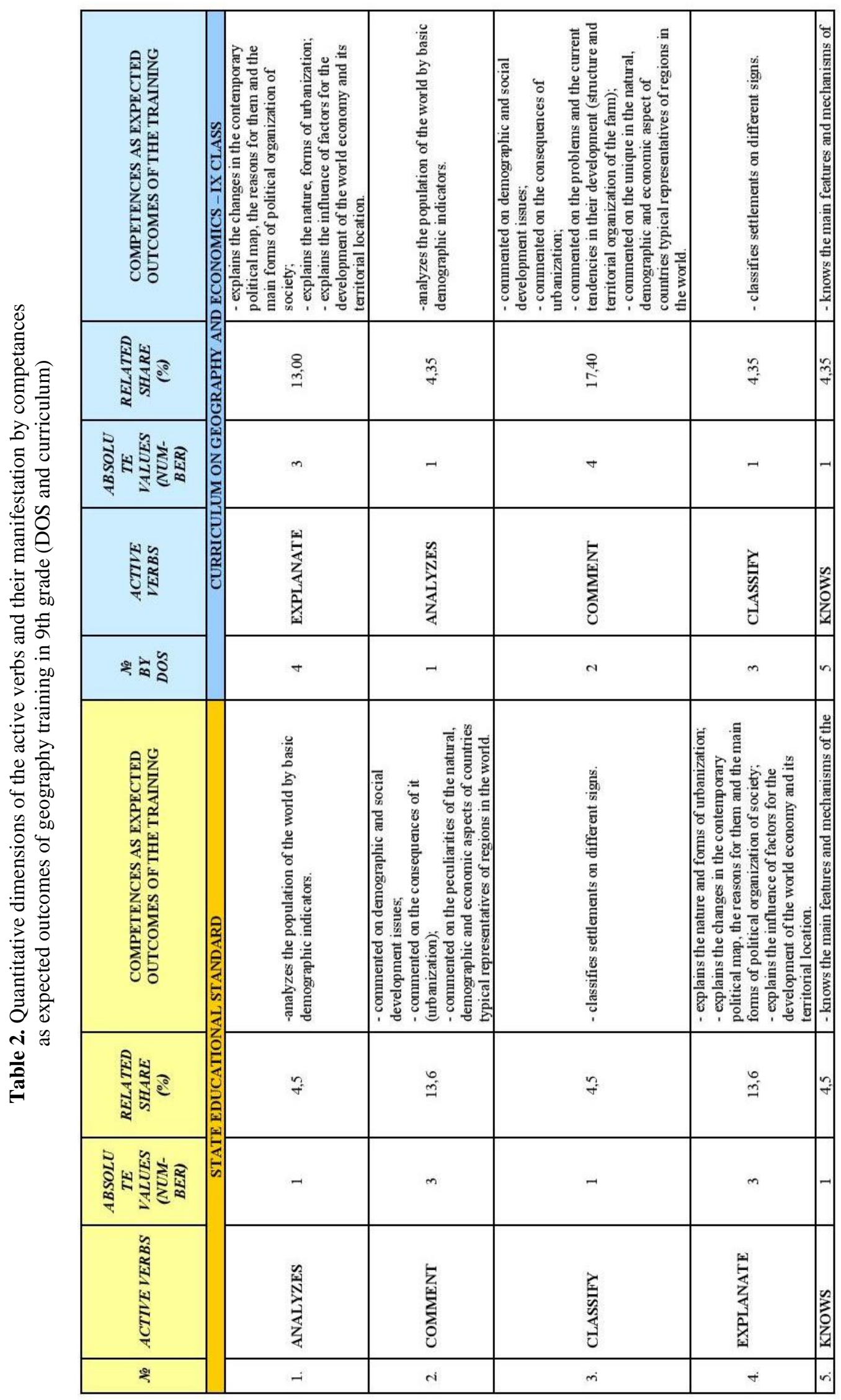




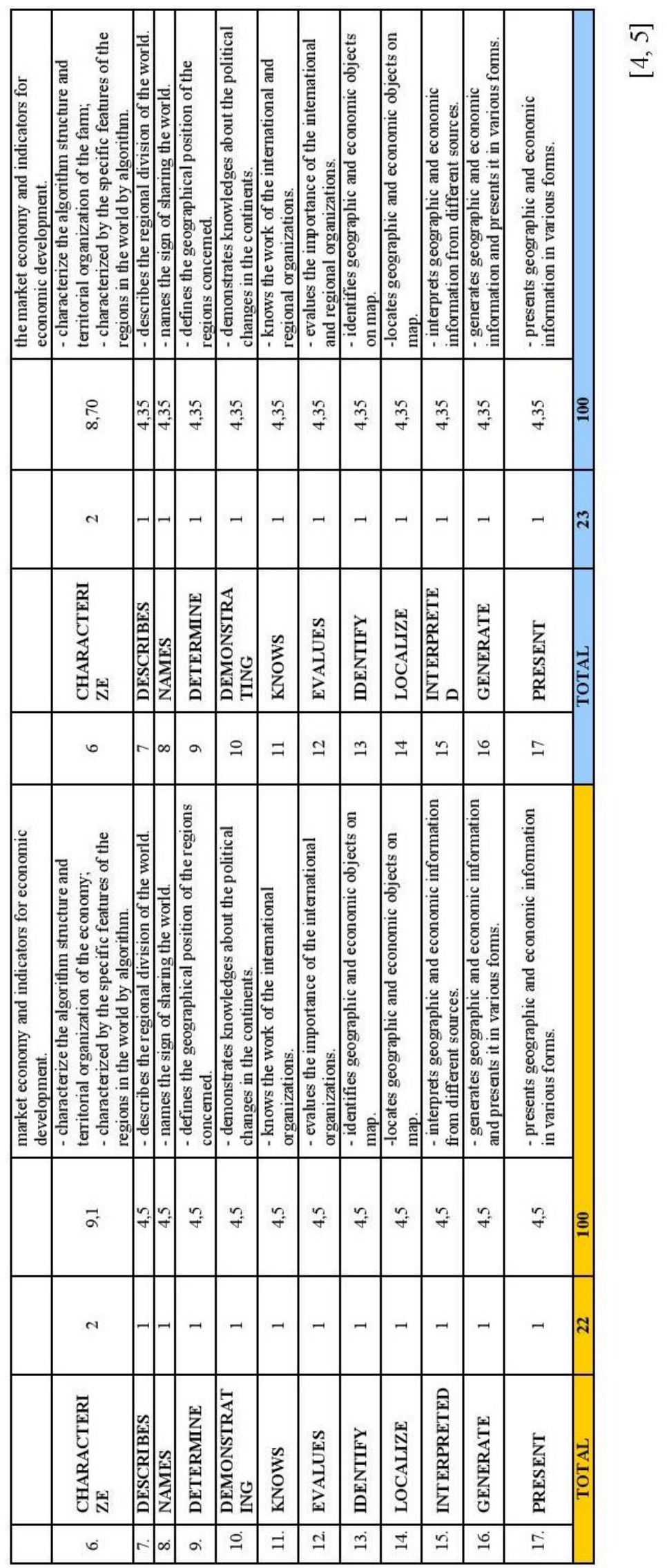


Horizontal links that synthesize school content in geography with the other school subjects are a new moment and challenge in the new geography curriculum. Horizontal synthesis is defined not on themes of the school content, but on the different key competences - a total of 11 school subjects (repeatedly referenced to nine key competences). [3] Each of the school subjects integrates knowledges, skills and attitudes not in their own aspect, but through a subject synthesis to develop learning, education and socialization processes through geography training in 9 class.

The school content, activities and horizontal links on the key competences in the curriculum follows the conceptual framework from the theoretical to the practical, to interact between the traditional and interactive teaching of the school content, aiming to preserve and develop the Bulgarian educational tradition.

\section{REFERENCES}

[1] Dermendzhieva, Stella. Metodika na izledovatelskata deinost po regionalna geografiya, V. Tarnovo, UNI „Sv. sv. Kiril i Metodiy”, 2001, pp. 14;

[2] Dermendzhieva, Stella, Petya Sabeva, Boyanka Dimitrova. Geografiya i obrazovanie. Metodika na obuchenieto po geografiya, I chast. V. Tarnovo, UNI „Sv. sv. Kiril i Metodiy”, 2010, pp 371;

[3] Draganova, Tamara. Conceptual analysis of the training on "Geography of countries" in the new realities by curricula - IX-th grade, Issue 41/International Scientific Refereed online Journal with Impact Factor - SocioBrains, Bulgaria, pp 30-35, 2018;

[4] Naredba № 5/30.11.2015 za obshtoobrazovatelnata podgotovka, Bulgaria, 2015.

[5] Uchebna programa po geografiya i ikonomika za IX klas (obshtoobrazovatelna podgotovka po ramkovi uchebni planove), Bulgaria, 2017;

[6] Zakon za preduchilishtnoto i uchilishtnoto obrazovanie, Bulgaria, 2016. 